\title{
Adsorption of Copper Using Pomelo Peel and Depectinated Pomelo Peel
}

\author{
Penpun Tasaso
}

\begin{abstract}
The removal of Copper $\left(\mathrm{Cu}^{2+}\right)$ from aqueous solution by adsorption on pomelo peel (PP) and depectinated pomelo peel (DPP) were studied. Factors affected to adsorption; initial $\mathbf{p H}$, initial concentration, contact time and temperature were investigated. It was found that the highest $\mathrm{Cu}^{2+}$ adsorption capacity for PP and DPP were $19.7 \mathrm{mg} / \mathrm{g}$ and $21.1 \mathrm{mg} / \mathrm{g}$ at the following conditions; $\mathrm{pH}=4,125 \mathrm{mg} / \mathrm{l}$ of initial concentration , temperature of $25{ }^{\circ} \mathrm{C}$ and equilibrium time about $60 \mathrm{~min}$. Adsorption isotherm of both PP and DPP were well described by the Langmuir model. The kinetic studies showed that a pseudo-second-order rate model was adopted to described the $\mathrm{Cu}^{2+}$ adsorption. The thermodynamics parameter of the $\mathrm{Cu}^{2+}$ adsorption were evaluated at temperature of 25,35 and $45^{\circ} \mathrm{C}$. The negative of standard free energy change and enthalpy change revealed that the adsorption process is spontaneous and exothermic.
\end{abstract}

Index Terms-Adsorption, copper, kinetics, pomelo peel.

\section{INTRODUCTION}

One of the heavy metals often found from industrial effluent is copper, which from cleaning and plating baths, paper board mills, wood pulp production and the fertilizer industry. This heavy metal is most toxic to living organism. The adsorption process has been widely studied in order to solve the problem of many industries regarding the disposal of their effluent. Systems such as ion exchange resins, electrochemical process, chemical precipitation and activated carbon have been widely used in the process of waste water treatment. Agricultural waste is one of the rich sources of low cost adsorbents besides industrial by-product and natural material. Due to its abundant availability agricultural waste such as rice husk, coconut shell, wheat bran and maize wrapper offer little economic value and moreover create disposal problem [1]. These agricultural by-products usually are composed of lignin and cellulose as major constituents and may also include other polar functional groups of alcohols, carboxylic, aldehydes, phenolic and ether groups. These groups have the ability to some extent to bind heavy metals by donation of an electron pair to form complexes with the metal ions in solution [2]. Pomelo peel is very interesting biosorbent because of their high pectin content [3] The main structural of pectin in plant cell wall based on $\alpha$-(1-4) linked D-galacturonic acid, which negative charges of free carboxyl groups in pectin molecules form the covalent bonds with two valence metal ions [4],[5]. Therefore the goal of this study is to investigate the adsorption behavior of

Manuscript received May 16, 2013; revised July 16, 2013.

Penpun Tasaso is with Department of Chemical Engineering, Faculty of Engineering, Mahidol University, Thailand (e-mail: penpun.tas@mahidol.ac.th). copper on pomelo peel and the remaining depectinated peel.

\section{ReSEARCH Methodology}

\section{A. Adsorbents preparation}

Pomelo Peel (PP) : the white albedo was separated from pomelo peels with a knife into a small piece and coarsely chopped with a food blender. It was washed several times with distilled water then washed three times with $95 \%$ ethanol to remove the impurities. The washed albedo was dried at $70{ }^{\circ} \mathrm{C}$ for $2-3 \mathrm{~h}$ then ground and sieved, size only smaller than $0.42 \mathrm{~mm}(<35 \mathrm{mesh})$ was used.

Depectinated Pomelo Peel (DPP): the DPP was the pomelo peel residues left after the extraction of pectin from the peels. The conditions for pectin extraction are hot acidified water at $\mathrm{pH}=1.5$ and temperature $115-120{ }^{\circ} \mathrm{C}$ for $60 \mathrm{~min}$. The filtrate was precipitated by $95 \%$ ethanol to get pectin, the residues solid, DPP was separated by filtration. It was washed several times with distilled water then dried at $70{ }^{\circ} \mathrm{C}$ for $2-3 \mathrm{~h}$, ground and sieved, size only smaller than $0.42 \mathrm{~mm}(<35$ mesh) was used.

\section{B. $\mathrm{Cu}^{2+}$ Adsorption}

\section{1) Effect of $p H$}

The effect of solution $\mathrm{pH}$ on the adsorption capacity of $\mathrm{Cu}^{2+}$ was invested at $\mathrm{pH} 3,4,5$ and 6 . The experiments were performed by adding $0.5 \mathrm{~g}$ of PP or DPP to $100 \mathrm{ml}$ of $25 \mathrm{mg} / 1$ standard copper solution and the $\mathrm{pH}$ of the solution was adjusted using $0.1 \mathrm{~mol} / 1 \mathrm{HCl}$ or $\mathrm{NaOH}$. The flask were shaken at $150 \mathrm{rpm}$ and $25{ }^{\circ} \mathrm{C}$ for $180 \mathrm{~min}$, the solution mixture were filtered to remove adsorbents and the filtrates were analyzed the $\mathrm{Cu}^{2+}$ concentration by atomic absorption spectrophotometer. The amount of copper adsorbed were determined as follows

$$
q=\frac{V\left(C_{0}-C_{f}\right)}{m}
$$

where $q$ is adsorption capacity in $(\mathrm{mg} / \mathrm{g}), C_{0}$ and $C_{f}$ are the initial and final copper concentration $(\mathrm{mg} / \mathrm{l})$ respectively, $V$ is the suspension volume (l) and $\mathrm{m}$ is the mass of the adsorbent materials (g).

\section{2) Effect of initial concentration and contact time}

Sorption equilibrium studies were conduct at optimum $\mathrm{pH}$ $=4$, the flask were shaken at $150 \mathrm{rpm}$ for $180 \mathrm{~min}$ at controlled temperature at $25{ }^{\circ} \mathrm{C}$. Isotherm studies were conducted with $0.5 \mathrm{~g}$ of PP or DPP and varying initial concentration of $\mathrm{Cu}^{2+}$ in the range of $25-125 \mathrm{mg} / \mathrm{l}$. 
The effect of contact time also studied to determine the adsorption kinetic of $\mathrm{Cu}^{2+}$. For batch kinetic studies, $0.5 \mathrm{~g}$ of PP or DPP were equilibrated at optimum condition, $\mathrm{pH}=4$ the flask were shaken at $150 \mathrm{rpm}$ with initial concentration between 25 - $125 \mathrm{mg} / \mathrm{l}$, temperature was controlled at $25{ }^{\circ} \mathrm{C}$, $0.5 \mathrm{ml}$ of sample were withdrawn at time interval between 0-180 min.

\section{3) Effect of temperature}

Effect of temperature on adsorption of $\mathrm{Cu}^{2+}$ was studied by conducting different sets of experiment, $0.5 \mathrm{~g}$ of PP or DPP were equilibrated at optimum condition, $\mathrm{pH}=4$, the flask were shaken at $150 \mathrm{rpm}$, initial concentration of 25,75 and $125 \mathrm{mg} / \mathrm{l}$ and temperature was controlled at various of 25, 35 and $45{ }^{\circ} \mathrm{C}$ with contact time of $180 \mathrm{~min}$.

\section{4) Copper analysis}

The $\mathrm{Cu}^{2+}$ in the solution was analyzed using atomic absorption spectrophotometer (Perkin Elmer model 3000) which operates in flame mode.

\section{5) FTIR spectra of adsorbent}

The adsorbents PP and DPP were analyzed the FTIR spectrum before and after copper ion adsorption using FT-IR (Perkin Elmer 2000)

\section{RESUlTS AND DisCUSSION}

\section{A. Effect of $p H$}

The effect of $\mathrm{pH}$ on the $\mathrm{Cu}^{2+}$ adsorption capacity of PP and DPP is found to be significant as shown in Fig. 1. The adsorption capacity of PP and DPP is found maximum at $\mathrm{pH}$ $=4$ and dramatic decreased at $\mathrm{pH}$ higher than 4 . Generally, as a result of net negative charge on the different functional group in the cell wall of adsorbents, the ionic state of the different functional such as carboxyl and hydroxyl groups favors reaction with $\mathrm{Cu}^{2+}[5]$. Under high acidic condition, the more proton are available in a free form to protonated carboxyl and hydroxyl groups caused to reduce the number of binding sites of PP and DPP as a result of decreasing the adsorption capacity. At higher $\mathrm{pH}$ values the insoluble copper complex starts precipitating from the solutions, which makes true adsorption studies impossible. The result suggests that initial $\mathrm{pH}$ would play and important factor in the adsorption of copper using PP and DPP.

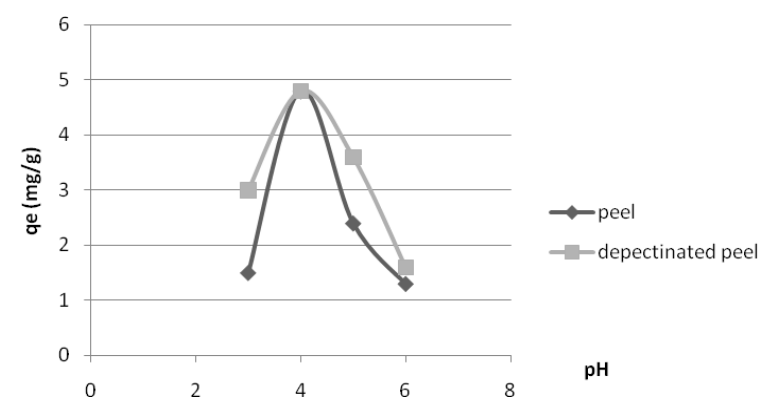

Fig. 1. Effect of initial $\mathrm{pH}$ on the adsorption capacity of $\mathrm{Cu}^{2+}$ on PPand DPP

\section{B. Effect of Initial Concentration and Contact Time}

The effect of $\mathrm{Cu}^{2+}$ initial concentration on the adsorption capacity of PP and DPP under optimum conditions of $\mathrm{pH}$ and contact time was shown in Fig. 2. The adsorption capacity increased with increasing of $\mathrm{Cu}^{2+}$ initial concentration in solution. The plateau value obtained as shown in Fig. 3 showed that as the metal/adsorbents ratio increases, there is a decrease in adsorption efficiency. This can be attributed to the saturation of the binding sites on the adsorbents.

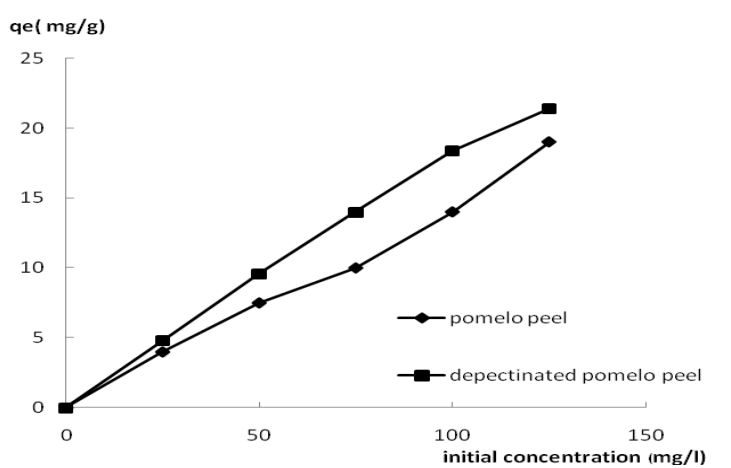

Fig. 2. Effect of initial concentration on the adsorption of $\mathrm{Cu}^{2+}$ on PP and DPP

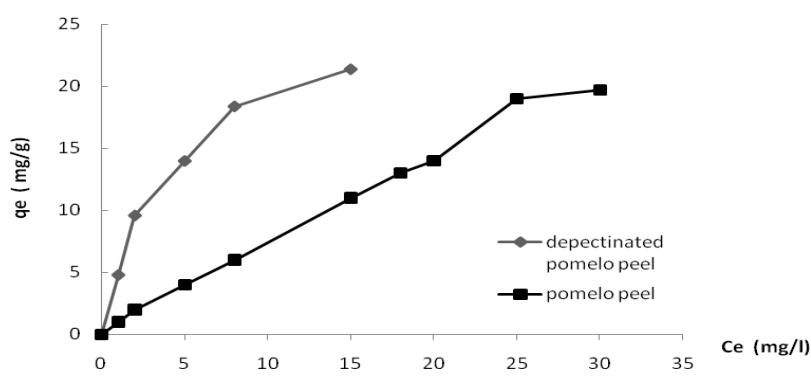

Fig. 3. Adsorption isotherm of $\mathrm{PP}$ and $\mathrm{DPP}$ at $\mathrm{pH}=4$ and $25^{\circ} \mathrm{C}$

The experimental data were also applied to adsorption isotherm both the Langmuir and Freundlich isotherm model.

The Langmuir equation is most often used to described equilibrium sorption isotherm [6], which is valid for monolayer sorption with a finite number of identical sites and is given by

$$
q_{e}=\frac{q_{\max } b C_{e}}{\left(1+b C_{e}\right)}
$$

where $q_{\max }$ is the maximum sorption at monolayer $(\mathrm{mg} / \mathrm{g}), \mathrm{Ce}$ is a final equilibrium concentration of $\mathrm{Cu}^{2+}, q_{e}$ is the $\mathrm{Cu}^{2+}$ bound per unit weight of the PP and DPP at final equilibrium concentration $(\mathrm{mg} / \mathrm{g})$ and $b$ is the Langmuir constant related to the affinity of binding sites $(\mathrm{ml} / \mathrm{mg})$. The following linearized plot of the Langmuir equation was used in this study.

$$
\frac{C_{e}}{q_{e}}=\frac{C_{e}}{q_{\max }}+\frac{1}{b q_{\max }}
$$

The widely used empirical Freundlich equation based on sorption on a heterogeneous surface is given by

$$
\log q_{e}=\log K_{F}+\frac{1}{n} \log C_{e}
$$

The linearized Langmuir isotherm for $\mathrm{Cu}^{2+}$ adsorbed on the PP and DPP adsorbent was shown in Fig. 4 and Fig. 5. The model parameters are given in Table I. 


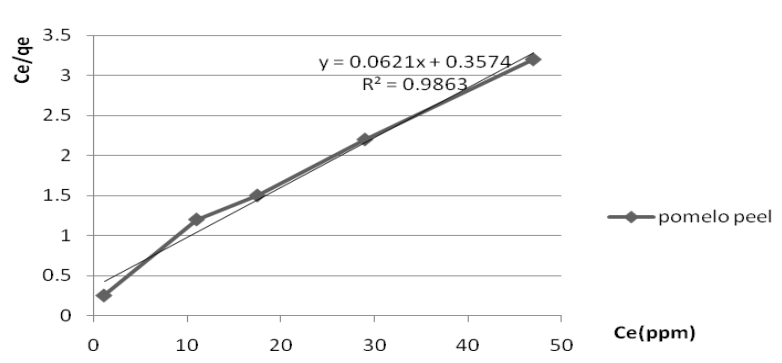

Fig. 4. Linearized Langmuir isotherm model of $\mathrm{Cu}^{2+}$ adsorption on pomelo peel

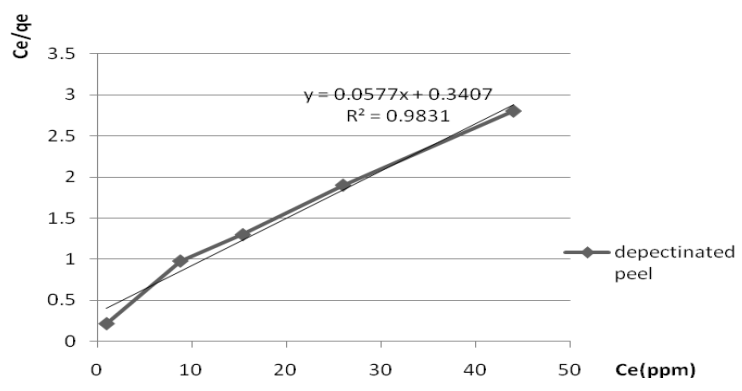

Fig. 5. Linearized Langmuir isotherm model of $\mathrm{Cu}^{2+}$ adsorption on depectinated pomelo peel

They showed that adsorption of $\mathrm{Cu}^{2+}$ by PP and DPP were better correlate $\left(\mathrm{R}^{2}>0.95\right)$ with the Langmuir equation as compared to Freunlich, indicating that adsorption of $\mathrm{Cu}^{2+}$ is more likely monolayer coverage on surface of PP and DPP

TABLE I: ISOTHERM PARAMETER OBTAINED BY USING LINEAR METHOD

\begin{tabular}{|c|c|c|c|}
\hline $\begin{array}{c}\text { Isotherm } \\
\text { model }\end{array}$ & Parameters & Pomelo peel & $\begin{array}{c}\text { Depectinated } \\
\text { pomelo peel }\end{array}$ \\
\hline \multirow{3}{*}{ Langmuir } & $\mathrm{R}^{2}$ & 0.9863 & 0.9831 \\
\cline { 2 - 4 } & $\mathrm{q}_{\mathrm{m}}(\mathrm{mg} / \mathrm{g})$ & 19.7 & 21.1 \\
\cline { 2 - 4 } & $\mathrm{b}(\mathrm{l} / \mathrm{mg})$ & 0.1748 & 0.1697 \\
\hline \multirow{3}{*}{ Freundlich } & $\mathrm{R}^{2}$ & 0.9439 & 0.5089 \\
\cline { 2 - 4 } & $\mathrm{K}_{\mathrm{F}}(\mathrm{l} / \mathrm{g})$ & 4.39 & 7.04 \\
\cline { 2 - 4 } & $\mathrm{n}$ & 3.0941 & 4.8924 \\
\hline
\end{tabular}

The effect of contact time on the adsorption capacity of DPP is as shown in Fig. 6. The increasing of initial metal concentration influenced to the increasing of contact time necessary to reach equilibrium and also increased the adsorption capacity .To analyze the adsorption rate of $\mathrm{Cu}^{2+}$ onto PP and DPP, two simple kinetic model were tested.

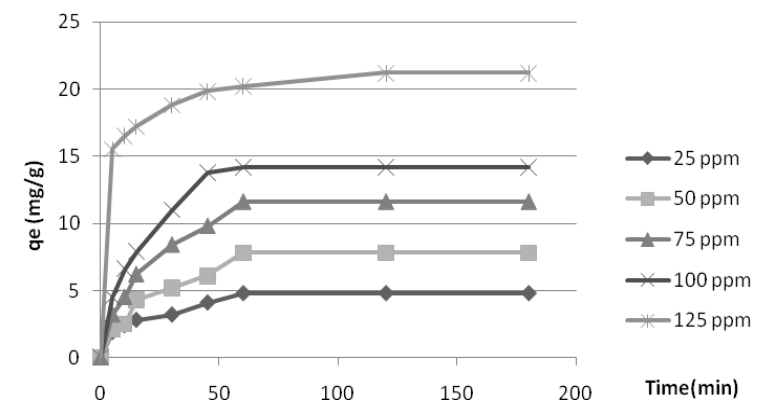

Fig. 6. Adsorption kinetic of depectinated pomelo peel at different initial concentration

Pseudo-first order model is generally described in the linearized version [7] by the following equation

$$
\ln \left(q_{e}-q_{t}\right)=\ln q_{e}-k_{1 a d} t
$$

where $q_{e}$ is the amount of $\mathrm{Cu}^{2+}$ adsorbed at equilibrium per unit weight of adsorbent $(\mathrm{mg} / \mathrm{g})$ and $\mathrm{q}_{\mathrm{t}}$ is the amount of $\mathrm{Cu}^{2+}$ adsorbed at any time $(\mathrm{mg} / \mathrm{g}), \mathrm{k}_{\text {lad }}$ is the rate constant $\left(\mathrm{min}^{-1}\right)$

The pseudo-second-order model is based on the assumption that adsorption follows a second order mechanism, whereby the rate of sorption is proportional to the square of the number of unoccupied sites. It is described in the linearized version by the following equation [7].

$$
\frac{t}{q_{t}}=\frac{1}{k_{2 a d}} q^{2}+\frac{t}{q_{e}}
$$

where $\mathrm{k}_{2 \mathrm{ad}}$ is the rate constant of second order. The linearized pseudo-second -order model gave a good fit with $\mathrm{R}^{2}$ were 0.99 either for PP and DPP. This means that the adsorption kinetic can be described by a pseudo-second-order rate equation hence $q_{e}$ and $k_{2 a d}$ were evaluated and presented in Table II.

TABLE II: RATE CONSTANT FOR CU2+ ADSORPTION ON PP AND DPP

\begin{tabular}{|c|c|c|c|c|c|c|c|}
\hline \multicolumn{4}{|c|}{ Pseudo-first order } & \multicolumn{5}{c|}{ Pseudo-second order } \\
\multicolumn{2}{|c|}{$\mathrm{k}_{1 \mathrm{ad}} \mathrm{q}_{\mathrm{e}}$} & $\mathrm{R}^{2}$ & $\mathrm{k}_{2 \mathrm{ad}} \mathrm{q}_{\mathrm{e}} \mathrm{q}_{\mathrm{e}}(\exp ) \mathrm{R}^{2}$ \\
\hline $\mathrm{PP}$ & 0.070 & 3.82 & 0.9931 & 0.081 & 19.69 & 19.7 & 0.9961 \\
\hline $\mathrm{DPP}$ & 0.060 & 2.82 & 0.8095 & 0.070 & 21.02 & 21.1 & 0.9974 \\
\hline
\end{tabular}

\section{Effect of Temperature}

In order to determine the thermodynamics parameters, experiments were carried out at three different temperature. $\left(25,35\right.$ and $\left.45{ }^{\circ} \mathrm{C}\right)$ The $\mathrm{Cu}^{2+}$ adsorption capacity decrease with increasing temperature as shown in Fig. 7. indicating that the reaction is exothermic. Thermodynamics parameters can be determined from the variation of the thermodynamic equilibrium constant $\mathrm{K}_{0}$ with temperature.

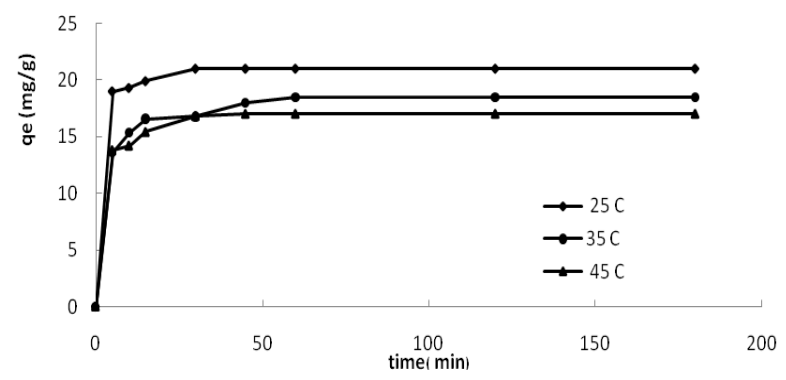

Fig. 7. Effect of temperature on the adsorption capacity of $\mathrm{Cu}^{2+}$ on DPP

For adsorption reactions, $\mathrm{K}_{0}$ is defined as follows :

$$
K_{0}=\frac{\gamma_{s} C_{s}}{\gamma_{e} C_{e}}
$$

where $C s$ is the surface concentration of $\mathrm{Cu}^{2+}(\mathrm{mmol} / \mathrm{g}), \mathrm{Ce}$ is the $\mathrm{Cd}^{2+}$ concentration in solution at equilibrium $(\mathrm{mmol} / \mathrm{ml})$, $\gamma_{s}$ and $\gamma_{e}$ are activity coefficient of the adsorbed $\mathrm{Cu}^{2+}$ and $\mathrm{Cu}^{2+}$ in solution respectively. As the $\mathrm{Cu}^{2+}$ concentration in solution declined to zero, $K_{0}$ can be obtained by plotting $\ln (\mathrm{Cs} / \mathrm{Ce})$ versus $C s$ and extrapolating $C s$ to zero. The straight line obtained is fitted by lease-square method Its intercepts with the vertical axis yields the value of $K_{0}$. The adsorption standard free energy change $\left(\Delta \mathrm{G}^{\circ}\right)$ can be calculated from

$$
\Delta G^{0}=-R T \ln K_{0}
$$

where $R$ is the universal gas constant $(8.314 \mathrm{~J} / \mathrm{mol} \mathrm{K})$ and $T$ is 
temperature in Kelvin. The average standard enthalpy change $\left(\Delta \mathrm{H}^{\circ}\right)$ is determined from the Van't Hoff equation[8].

$$
\ln K_{0}\left(T_{3}\right)-\ln K_{0}\left(T_{1}\right)=\frac{\Delta H^{0}}{R}\left(\frac{1}{T_{3}}-\frac{1}{T_{1}}\right)
$$

The standard entropy change $\left(\Delta \mathrm{S}^{\circ}\right)$ is given by

$$
\Delta S^{0}=\frac{-\left(\Delta G^{0}-\Delta H^{0}\right)}{T}
$$

The value $\mathrm{K}_{0}$ of $\mathrm{Cu}^{2+}$ adsorption on PP and DPP were evaluated and plots was shown in Fig. 8. and all thermodynamic parameters of $\mathrm{Cu}^{2+}$ adsorption on PP and DPP were presented in Table III. A negative standard enthalpy change of $-32.18 \mathrm{~kJ} / \mathrm{mol}$ of PP and $-24.89 \mathrm{~kJ} / \mathrm{mol}$ of DPP obtained in this study indicates that the adsorption system is exothermic . Negative value of $\Delta \mathrm{G}^{\circ}$ confirmed that the feasibility of the spontaneous nature of adsorption. This is also confirms the possibility of physical adsorption.

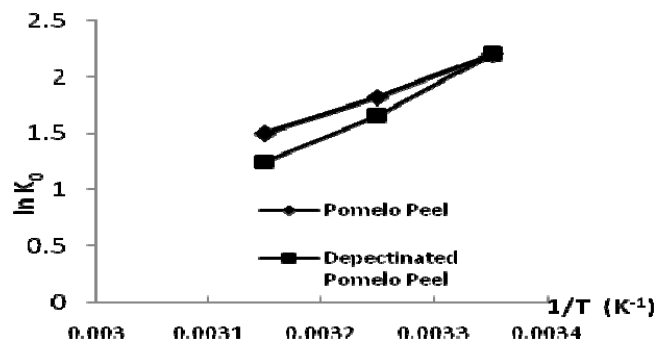

Fig. 8. plots of $\mathrm{K}_{0}$ at various temperature

TABLE III: VALUES OF THERMODYNAMICS PARAMETERS FOR $\mathrm{CU}^{2+}$

\begin{tabular}{|c|c|c|c|c|c|}
\hline Adsorbents & $\begin{array}{l}\text { Temp } \\
(\mathrm{K})\end{array}$ & $\mathrm{K}_{0}$ & $\begin{array}{l}\Delta \mathrm{G}^{\circ} \\
(\mathrm{kJ} / \mathrm{mo})\end{array}$ & $\Delta \mathrm{H}^{\circ}(\mathrm{kJ} / \mathrm{mol})$ & $\begin{array}{l}\Delta \mathrm{S}^{\circ} \\
(\mathrm{kJ} / \mathrm{mol})\end{array}$ \\
\hline \multirow{3}{*}{ PP } & 298 & 8.77 & -5.38 & \multirow{3}{*}{-32.18} & \multirow{3}{*}{0.09} \\
\hline & 308 & 5.13 & -4.19 & & \\
\hline & 318 & 3.74 & -3.49 & & \\
\hline \multirow{3}{*}{ DPP } & 298 & 8.86 & -5.40 & \multirow{3}{*}{-24.89} & \multirow{3}{*}{0.08} \\
\hline & 308 & 6.32 & -4.72 & & \\
\hline & 318 & 4.58 & -4.02 & & \\
\hline
\end{tabular}
ADSORPTION ON PP AND DPP

\section{FT-IR Spectra of PP and DPP}

The FT-IR spectra of PP and DPP are presented in Fig. 9 and Fig. 10 respectively. To observe which peak shift during adsorption, the FT-IR before and after adsorption of PP and DPP were compared. All spectra of PP and DPP before adsorption show the $1650-1600 \mathrm{~cm}^{-1}$ bands represented the free carboxylate groups and typical peaks for $-\mathrm{OH}$ group at $3424-3250 \mathrm{~cm}^{-1}$. But after adsorption the $\mathrm{COO}^{-}$.peak of both PP and DPP shifted pronouncedly by $30 \mathrm{~cm}^{-1}$, clearly demonstrating the involvement of this group in $\mathrm{Cu}^{2+}$ sorption.

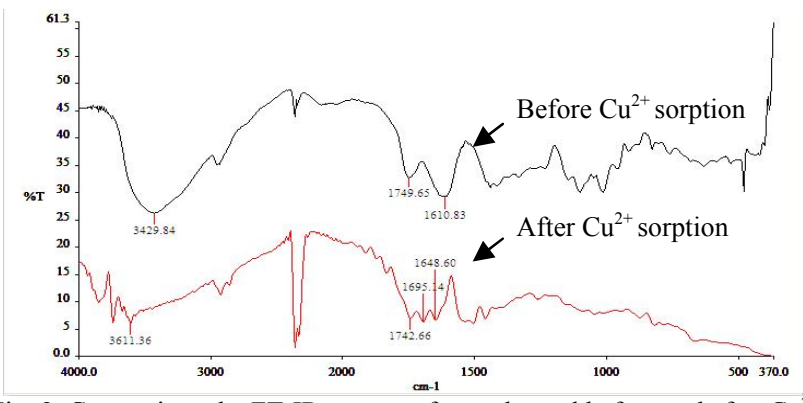

Fig. 9. Comparison the FT-IR spectra of pomelo peel before and after $\mathrm{Cu}^{2+}$ adsorption

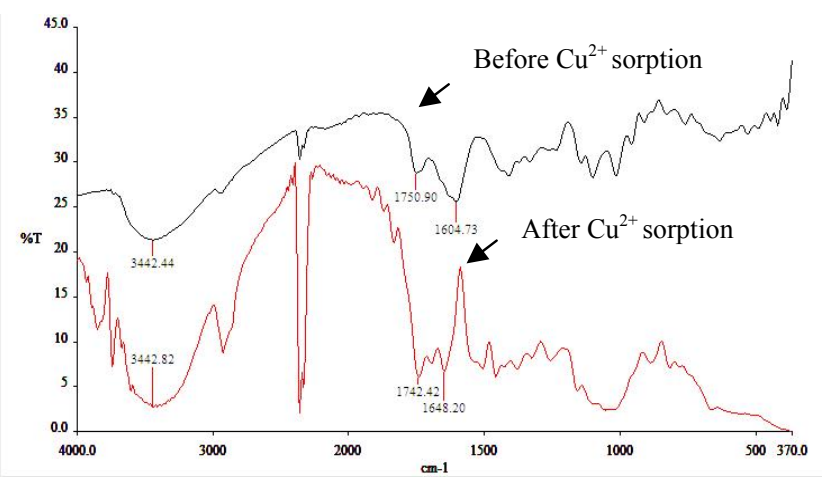

Fig. 10. Comparison the FT-IR spectra of depectinated pomelo peel before and after $\mathrm{Cu}^{2+}$ adsorption

\section{CONCLUSION}

Adsorption of copper from aqueous solution was possible using pomelo peel and depectinated pomelo peel. Equilibrium study showed that Langmuir isotherm is well fitted. The pseudo-second - order rate model fits very well with this adsorption kinetic. Thermodynamics constant of the $\mathrm{Cu}^{2+}$ adsorption were evaluate at temperature of 25,35 and $45{ }^{\circ} \mathrm{C}$. The results of $\Delta \mathrm{H}^{\circ}, \Delta \mathrm{S}^{\circ}$ and $\Delta \mathrm{G}^{\circ}$ of all adsorbent were -32.2 to $-24.9 \mathrm{~kJ} / \mathrm{mol}, 0.09-0.06 \mathrm{~kJ} / \mathrm{mol}$ and -4.7 to -4.4 $\mathrm{kJ} / \mathrm{mol}$ respectively. The negative value of standard enthalpy change and standard free energy change suggested that the adsorption of copper by pomelo peel and depectinated pomelo peel was exothermic and spontaneous.

\section{REFERENCES}

[1] C. J. Igwe and A. A. Abia, "Adsorption kinetics and intra particulate diffusivities for bio remediation of $\mathrm{Co}$ (II), $\mathrm{Fe}$ (II) and $\mathrm{Cu}$ (II) ions from waste water using modified and unmodified maize cob," International Journal of Physics Sciences, vol. 25, pp.119-127, 2007.

[2] F. Pagnanelli, S. Mainelli, F. Veglio, and L. Toro, "Heavy metal removal by olive pomace: biosorbent characterization and equilibrium modeling," Chemical Engineering Science, vol. 58, pp. 4709-4717, 2003

[3] P. Tasaso, "Extraction of pectin from pomelo peel with optimisation by response surface methodology," Presented at Regional Symposium on Chemical Engineering; $17^{\text {th }} 2010$ Nov 22-23; Queen Sirikit National Convention Center, Bangkok, Thailand.

[4] S. Schiewer and M. Iqbal. "The role of pectin in Cd binding by orange Peel biosorbents:A comparison of peels, depectinated peels and pectic acid," Journal of Hazardous Materials, vol. 177, pp. 899-907, 2010.

[5] M. Khotimchenko, V. Kovalev, and Y. Khotimchenko, "Equilibrium studies of sorption of lead(II) ions by different pectin compounds," Journal of Hazardous Materials, vol. 149, pp. 693-699, 2007.

[6] S. Schiewer and S. B. Patil, "Pectin-rich fruit waste as biosorbents for heavy metal removal: Equilibrium and kinetics," Bioresource Technology, vol. 99, pp. 1896-1903, 2008.

[7] N. A. Adesola Babarinde, J. O. Babalola, and O. B. Adebisi, "Kinetic, isotherm and thermodynamic studies of the biosorption of zinc(II) from solution by maize wrapper," International Journal of Physics Sciences, vol. 25, pp.119-127, 2007.

[8] Y. H. Huang, C. L. Hsueh, H. P. Cheng, L. C. Su, and C. Y. Chen, "Thermodynamics and kinetics of adsorption of $\mathrm{Cu}$ (II) onto waste iron oxide," Journal of Hazardous Materials., vol.144, pp. 406-411, 2007.

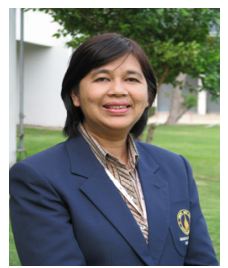

P. Tasaso obtained B.Sc. in Chemical Eng, M. Eng. in Chemical Eng. At present she is an Assist Prof. Department of Chemical Engineering, Mahidol University. Her areas of interest are extraction of valuable products from agricultural waste and environmental monitoring. She is member of Thai Institute of Chemical Engineering and Applied Chemistry. 